\title{
Tieto- ja \\ viestintätekniikka ja työssä oppiminen
}

\section{- (mikro)kertomuksia esiopetuksesta}

\author{
بैy \\ Päiväkodin rutiinia arvostava työkulttuuri voi joskus hankaloittaa \\ uusien tapojen kehittämistä. Esiopetuksessa työskentelevät \\ opettajat tarvitsevat paitsi tietoa, myös aikaa ja rohkaisua \\ tieto- ja viestintätekniikan käyttämiseen lasten kanssa.
}

ע

UUSISSA, VIIMEISTÄÄN elokuussa 2016 käyttöönotettavissa esiopetuksen opetussuunnitelman perusteissa tieto- ja viestintätekninen (TVT) osaaminen on nimetty laaja-alaiseksi osaamisalueeksi ja TVT:n hallinta nähdään välttämättömänä vuorovaikutus-, opiskelu- ja työelämätaitona (Opetushallitus 2014, 18). Vielä tällä hetkellä TVT:aa ei lasten kanssa laajamittaisesti käytetä esiopetuksessa. Reunamon, Söderqvistin ja Tannerin (2014, 162-165) Keski-Uudellemaalle ja Hämeenlinnaan kohdistuneen kartoituksen mukaan vain kolme prosenttia esiopetustiimeistä mieltää väittämän "ryhmässä käytetään runsaasti tieto- ja viestintätekniikkaa" kuvaavan ryhmäänsä vähintään melko hy- vin. Esiopetuksen laadunarviointiraportin (Hujala ym. 2012) perusteella syynä tähän on laitteiden puute. Tämä tarkoittaa, että vain harvalla esiopetuksen työntekijällä on kokemusta TVT:n käytöstä lasten kanssa. Lisäksi varhaiskasvatuksen koulutuksen laadunarvioinnin (Karila ym. 2013; ks. myös Pääjärvi \& Mertala 2015) mukaan TVT-taidot ovat yliopistollisen lastentarhanopettajakoulutuksen heikoin osaalue. Tätä vasten onkin selvää, että uusien esiopetuksen opetussuunnitelman perusteiden TVT-linjaukset ovat merkittävä muutos esiopetushenkilöstön osaamisvaatimuksiin.

Engeströmin, Kerosuon ja Kajamaan $(2008,20)$ mukaan tyypillinen reaktio työelämän muutoshaas- 
teisiin ovat erilaiset kehittämishankkeet. Tieto- ja viestintätekniikkaan keskittyviä kehittämis- ja tutkimushankkeita on tehty päiväkodeissa 1990-luvun alusta lähtien (esim. Kankaanranta 1999; Pekkarinen 2001; Reunamo 2003; Siekkinen \& Ojala 1996), ja tätä kirjoittaessani käynnissä on useita hankkeita ympäri Suomea ${ }^{1}$. Hanke on kuitenkin historiaton ja tulevaisuudeton projekti (Seppänen-Järvelä 2006), ja tukitoimien loppuessa loppuu usein myös työn kehittäminen (Tondeur, Coopert \& Newhouse 2010). Mediakasvatus- ja koulutusteknologiahankkeiden keskimääräinen kesto on 18 kuukautta (Palsa, Pääjärvi, Tossavainen \& Pekkala 2014, 13), mutta esimerkiksi Orlandon (2014) seurantatutkimuksessa merkittäviä muutoksia opettajien TVT:n käytössä alkoi tapahtua aikaisintaan kolmannen vuoden kohdalla ja usein vasta viidentenä seurantavuonna. Tapahtuneet muutokset poikkeavat myös usein niistä tavoitteista, joita hankesuunnitelmiin on kirjattu (Engeström, Kerosuo \& Kajamaa 2008, 20-21). Täten esimerkiksi yksittäisiä koulutuksia merkittävämmäksi tekijäksi voidaankin ajatella se, millaista työssä oppimista työpaikan arjessa koulutuksen jälkeen tapahtuu, ja millaiset ovat ylipäätään työssä oppimisen edellytykset.

Artikkelissani käsittelen päiväkotityön ominaispiirteiden merkitystä työssä oppimisen edellytyksille hankekontekstissa. Ominaispiirteillä tarkoitan esimerkiksi päiväkotityön perinteitä. Hankekontekstilla tarkoitan vuosina 2013-2015 toteutettua, tieto ja viestintätekniikan pedagogiseen käyttöön keskittynyttä kehittämishanketta, jonka aika- ja tavoitekehyksien kautta työssä oppimiseen liittyviä havaintojani käsittelen. Empiirinen aineisto koostuu haastatteluista ja tutkimuspäiväkirjamerkinnöistä.

TVT-integraatiota käsittelevää tutkimuskirjallisuutta lukiessani olen kokenut raportointikäytäntöjen kadottavan usein opettajat (ja muut toimijat) kokevina ja tuntevina subjekteina kasvottoman ja toteavan ilmaisun taakse. Aineistoina käytetään usein kyselyjä (esim. Gialamas \& Nikolopoulou 2010; Kerckaert, Vanderlinde \& van Braak 2015) ja pienempiotantaisissa tapaustutkimuksissakin fokus on usein interventioiden vaikuttavuudessa (esim. Angeli 2004; Tondeur, Coopert \& Newhouse 2010). Tällaisia lähestymistapoja voidaan pitää ominaisina Jerome
Brunerin (1986) määrittelemälle paradigmaattiselle tietämisen tavalle, jossa korostuvat kausaalisuhteet ja ilmaisujen eksaktius. Artikkelissani tukeudunkin kerronnalliseen tietämisen tapaan, jossa pyrkimyksenä on ymmärtää inhimillistä toimintaa johdonmukaisen kertomuksen tuottamisen kautta. (Bruner 1986; Heikkinen 2002; Polkinghorne 1995.) Artikkelin aluksi käyn läpi työssä oppimista ja päiväkotityön ominaispiirteitä. Sen jälkeen esittelen kontekstin, aineiston ja käyttämäni analyysimetodin. Tulosluvussa käsittelen ensin työssä oppimisen edellytyksiä kolmesta mikrokertomuksesta konstruoimani kehyskertomuksen kautta. Sen jälkeen käyn keskustelua kertomuksesta tekemieni tulkintojen ja aiemman tutkimuskirjallisuuden kesken.

\section{PÄIVÄKOTI TYÖSSÄ OPPIMISEN KONTEKSTINA}

Erona formaalille työpaikkakoulutukselle arjessa tapahtuvaa työssä oppimista luonnehtii epämuodollisuus, satunnaisuus, käytäntösidonnaisuus ja sosiaaliuus. Oppimisen mahdollisuudet ovat lisäksi vahvasti työtehtävien määrittelemiä. (Collin 2005, 15-26; Saari 2013.) Kontekstin ja sosiaalisuuden näkökulmasta päiväkotityön erottaa muusta institutionaalisesta kasvatuksesta sen moniammatillisuus. Kasvatuksesta ja opetuksesta ei vastaa yksittäinen opettaja vaan lastentarhanopettajista ja lastenhoitajaista koostuva moniammatillinen tiimi (Venninen 2007, 23-26). Työtehtävien suhteen vallalla on usein "kaikki tekee kaikkea” -työkulttuuri, jonka myötä työtehtävät ovat muuttuvia ja vastuut ja velvoitteet epäselviä (Karila \& Kupila 2010, 37-41; Karila \& Nummenmaa 2001, 39-40). Esiopetus on kuitenkin kelpoisuusasetusten ja toimintakulttuurinsa suhteen opetuspainotteisempaa, ja lastentarhanopettajien ja lastenhoitajien vastuut ovat selkeämmin erilaiset kuin muussa päiväkotityössä (Karila \& Nummenmaa 2001, 38; Rutanen \& Karila 2013, 20-21; Ylitapio-Mäntylä 2009, 200-204). Esiopetuksessakaan lastentarhanopettajien työaika ei perustu opetusvelvollisuuteen vaan viikkotyöaikaan (38 h 15 min), josta noin 8 prosenttia (3 h) on varattu lapsiryhmän ulkopuolisiin tehtäviin kuten toiminnan suunnitteluun, vanhempien tapaamiseen ja opetussuunnitelmien laatimiseen (Lastentarhanopettajien työaikaa ... 2010,2-5). 
Aro (2006, 217-218) nimeää työssä oppimisen ja itsensä kehittämisen edellytyksiksi myös rauhalliset olosuhteet ja vakaat työsuhteet. Päiväkotityössä vakautta ja rauhaa haastavat naisvaltaisille aloille ominainen runsas vaihtuvuus (Venninen 2007, 25) sekä työssä koettu jatkuva kiire (Karila \& Kupila 2010, 34-37). Yksi vaihtuvuutta lisäävä tekijä on työkierto eli kotiryhmän säännönmukainen vaihtuminen usein kokonaisiin toimintavuosiin sidottujen ajanjaksojen välein. Työkiertoa perustellaan työyhteisön toimivuuden ylläpitämisellä sekä kokemuksen ja tiedon jakamisella. Työkierrosta on tunnistettu kuitenkin myös kuormittavia piirteitä (Rouvinen 2007, 151-152; Ylitapio-Mäntylä 2009, 201-204), ja uudelta jäseneltä odotetaan ennemmin vallitseviin käytäntöihin sopeutumista kuin niiden uudistamista (Karila \& Kupila 2010, 54-60).

\section{EMPIIRINEN KONTEKSTI JA TUTKIMUSAINEISTO}

Tutkimuksen empiirinen aineisto on kerätty osana esiopetuksen oppimisympäristöjen kehittämishanketta, jossa olen toiminut sekä tutkijana että kouluttajana. Pituudeltaan (20 kk) kyseessä on tyypillinen mediakasvatushanke (Palsa ym. 2014, 13). Hankkeeseen osallistui viisi esiopetusryhmää ja aineistoa on kerätty yhteensä 34 informantilta. Heistä viisi oli päiväkodin johtajia, kaksi varajohtajia, viisitoista lastentarhanopettajia, kymmenen lastenhoitajia ja kaksi ryhmäavustajia. Kahta lukuun ottamatta kaikki olivat naisia. Hankkeen tavoitteena oli valmiiksi määriteltyjen sisältöjen sijaan kehittää yhteistyössä jokaisen osallistuvan tiimin kanssa heidän erilaiset tarpeensa ja valmiutensa huomioivia persoonallisia pedagogisia käytänteitä. Yhteiset työpaikkakoulutukset keskittyivät pääasiassa pedagogisiin sisältöihin, ja osallistuvilta päiväkodeilta edellytettiin säännöllisen suunnitteluajan järjestämistä tiimeille laitteiden käytön opettelua/harjoittelua ja toiminnan suunnittelua varten. Jokainen tiimi valitsi keskuudestaan yhteyshenkilön, jonka kautta viestintä tutkija-kouluttajan kanssa pääasiallisesti tapahtuisi. Muut vastuut olisivat yhteisiä. Hankkeen vaiheet ja niistä tähän tutkimukseen kerätyt aineistot on esitetty koontina taulukossa $1{ }^{2}$

Taulukkoon merkittyjen tapaamisten lisäksi vierailin ryhmissä päivittämässä ja huoltamassa laitteita. Käynneistä ja niiden aikana tehdyistä havainnoista sekä informanttien kanssa käymistäni puhelin- ja sähköpostikeskusteluista on kirjattu merkinnät tutkimuspäiväkirjaan. Lokakuussa 2013 tehdyt haastattelut olivat teemahaastatteluja, joiden tarkoituksena oli selvittää esimerkiksi hakemisprosessin kulku, odotukset hanketta kohtaan, tiimien näkemykset omista vahvuuksistaan ja osallistujien käsitykset TVT:n roolista esiopetuksessa. Haastatteluja hyödynnettiin laitehankintojen, koulutussisältöjen ja koulutusmuotojen suunnittelussa. Syksyn 2014 ja kevään 2015 haastattelut olivat vapaamuotoisempia ja haastateltavien itsensä esiin nostamat asiat saivat määritellä sen, mitkä muodostuisivat haastattelujen keskusteemoiksi. Aineistoa voidaan pitää tyypillisenä monimuotoisena kenttäaineistona, joka sisältää sekä numeerista (esim. koulutusten osallistujamäärät) että

Taulukko 1. Kehittämishankkeen vaiheet ja kerätty aineisto.

\begin{tabular}{|c|c|c|}
\hline AIKA & HANKETEHTÄVÄT & KERÄTTY AINEISTO \\
\hline Syksy 2013 & Haastattelut & Haastattelulitteraatit \\
\hline Kevät 2014 & $\begin{array}{l}\text { TVT-infran rakentaminen } \\
\text { Koulutus } 1 \\
\text { Koulutus } 2 \\
\text { Yhteyshenkilöiden tapaaminen }\end{array}$ & $\begin{array}{l}\text { Koulutuksista ja laitteistoasennuskäynneistä tehdyt } \\
\text { tutkimuspäiväkirjamerkinnät } \\
\text { Yhteyshenkilöiden tapaamisen litteraatti }\end{array}$ \\
\hline Syksy 2014 & $\begin{array}{l}\text { Pedagoginen kahvila } 1 \\
\text { Pedagoginen kahvila } 2 \\
\text { Pedagoginen kahvila } 3 \\
\text { Pedagoginen kahvila } 4 \\
\text { Haastattelut }\end{array}$ & $\begin{array}{l}\text { Pedagogisista kahviloista tehdyt tutkimuspäiväkirjamerkinnät } \\
\text { Haastattelulitteraatit }\end{array}$ \\
\hline Kevät 2015 & $\begin{array}{l}\text { Osallistavat koulutuspäivät } \\
\text { Haastattelut }\end{array}$ & $\begin{array}{l}\text { Koulutuspäivistä tehdyt tutkimuspäiväkirjamerkinnät } \\
\text { Haastattelulitteraatit }\end{array}$ \\
\hline
\end{tabular}


kirjallista informaatiota (esim. haastattelulitteraatit) (Czarniawska 1998, 65). Aineistosta voidaan erottaa myös informanttien tuottama ja heistä tuotettu aineisto. Informanttien tuottamalla aineistolla tarkoitan heidän itse tuottamiaan haastatteluaineistoja ja tutkimuspäiväkirjaan kirjattuja suoria sitaatteja. Heistä tuotetulla aineistolla tarkoitetaan muiden informanttien heitä koskevaa haastattelukerrontaa sekä havaintopäiväkirjaan kirjattuja tulkitsevia merkintöjä.

\section{ANALYYSI}

Kerronnallisuus voi viitata tutkimuksen aineistoon tai sen käsittelytapaan. Kertomusten analyysissa (analysis of narratives) aineisto ymmärretään kertomuksina, joista pyritään kategorisoimaan esimerkiksi erilaisia kerronnan muotoja. Kerronnallisessa analyysissa (narrative analysis) tutkija pyrkii juonellisuuden kautta yhdistämään yksittäiset ja erilliset aineistot koherentiksi temaattiseksi kertomukseksi. (Heikkinen 2002, 191-193; Polkinghorne 1995, 13-21.) Kertomuksia voidaan tarkastella myös sen perusteella, miten ne asettuvat suhteessa toisiinsa. Yksi mahdollisuus on tehdä ero "pienten ihmisten" kertomusten (mikro) ja "virallisten" kertomusten (makro) välille (Boje 2001; Czarniawska 1998). Mikrokertomukset voidaan ymmärtää myös makrokertomuksia haastavina kertomuksina (Boje 2001, 45-61; ks. myös Bamberg 2004) ja Czarniawskan (1998) mukaan tällaisille mikrokertomuksille tyypillistä on altavastaajan puolelle asettuminen. Valtaan ja jännitteisiin perustuvan lähestymistavan vaihtoehdoksi hän tarjoaa tulkintaa, jossa makrokertomus muodostetaan useiden mikrokertomusten ympärille. (Czarniawska 1998, 49.)

Heikkisen $(2002,195)$ mukaan kerronnallisessa raportoinnissa "[o]leellista on, että tarinan maailma avautuu kuulijalle uskottavana siten, että kuulija alkaa eläytyä tarinan henkilöiden asemaan ja ymmärtää heidän toimintansa vaikuttimia niissä olosuhteissa, joissa he elävät". Tutkijan on kuitenkin oltava sensitiivinen sille, millaisia kertomuksia hänen keräämänsä aineisto antaa mahdollisuuden tuottaa ja tuoda julki raportissaan myös aineiston rajoitukset. Estola (2003) kuvaa aineiston rajaamista kerronnallisen analyysiprosessin kriittisimmäksi vaiheeksi ja korostaa, kuinka suoratkin aineistositeeraukset ovat viime kädessä tutkijan ääntä, koska sekä ne että se argumentatiivinen konteksti, jossa otteet esitetään, ovat tutkijan tekemiä valintoja. Mikrokertomuksille ominaisen altavastaaja-asetelman muodostumisen näkökulmasta esimerkiksi tämän tutkimuksen aineisto on epäedullinen johtajien kannalta, heidän ollessa korkeimmassa virka-asemassa olevat informantit. Jos aineistoa olisi kerätty myös varhaiskasvatuksen päälliköiltä, olisi se positioinut päiväkodin johtajat erilaiseen asemaan aineistossa ja tehnyt näkyvämmäksi (ja konkreettisemmaksi) hallinnollisen ja pedagogisen johtamisen ristipainetta ja johtajien esimiesten esimiestyön laatua (ks. Fonsén 2014, 156-159). Tästä syystä tukeudunkin Czarniawskan (1998) näkemykseen makrokertomuksesta mikrokertomusten kollaasina. Tutkimukseni kohdejoukon pienuuden huomioiden koen sopivammaksi käyttää makrokertomuksen sijasta kehyskertomusta kuvaamaan yksittäisten toimijoiden tarinoista konstruoimaani kertomusta.

Aineiston analyysiprosessi muodostui kolmivaiheiseksi. Ensimmäinen vaihe on lähinnä kertomusten analyysia ja toinen ja kolmas vaihe kerronnallista analyysia. Czarniawskan (1998, 65-72) tavoin ymmärrän analyysivaiheessa tapahtuvan lukemisen ja kirjoittamisen toisistaan erottamattomina prosesseina, ja jokainen lukukierros on tuottanut aina merkintöjä ensin litteraattien ja myöhemmin konstruoitujen mikrokertomusten ja kehyskertomuksen marginaaleihin. Esiopetuksen muusta varhaiskasvatuksesta poikkeavien kelpoisuusvaatimusten vuoksi koin perustelluksi keskittyä opettajiin ja johtajiin. Ensimmäisessä vaiheessa kokosin eri informanttien tuottamat ja heistä tuotetut aineistot omiksi jatkumoikseen. Niiden rinnakkaisella lukemisella pyrin tunnistamaan informaatioarvoltaan rikkaimmat kertomukset eli ne, jotka samanaikaisesti sisälsivät myös muista kertomuksista löytyviä elementtejä, mutta myös jotain ainutkertaista. Kehyskertomuksen kannalta tärkeänä tekijänä pidin sitä, että mikrokertomukset olisivat useammasta eri päiväkodista. Luennan myötä päädyin valitsemaan kolme informanttia kertomuksen keskushenkilöiksi. Heistä Tuula ja Anja olivat lastentarhanopettajia ja Kirsi päiväkodinjohtaja. 
Toisessa vaiheessa kirjoitin Tuulan, Anjan ja Kirsin tuottamien ja heistä tuotettujen aineistojen pohjalta heidän omat kronologisesti etenevät kertomuksensa. Kolmannessa vaiheessa kokosin Tuulan, Anjan ja Kirsin erilliset kertomukset yhdeksi kehyskertomukseksi, jonka seuraavaksi esittelen.

\section{KEHYSKERTOMUS 3}

Hankerahoituksen varmistuttua kunnallisten päiväkotien johtajille lähetettiin sähköpostitiedote, jossa kerrottiin lyhyesti hankkeesta ja pyydettiin kiinnostuneita olemaan yhteydessä varhaiskasvatuspalvelujen yhteyshenkilöön. ${ }^{4}$ Niittyvillan päiväkodinjohtaja välitti viestin esiopetusryhmään. Anja, nuori ja ensimmäistä vuotta esiopetuksessa työskennellyt opettaja innostui mahdollisuudesta. Hän käytti TVT:aa runsaasti vapaa-ajallaan ja oli aiemmin osallistunut mediakasvatuskoulutukseen. Toinen ja kokeneempi opettaja Hilkka ei pitänyt teknologiaa samalla tavoin omana alueenaan, mutta oli valmis lähtemään mukaan, koska uskoi saavansa Anjalta ja lastenhoitaja Meeriltä tukea ja apua. ${ }^{5}$ Samoin Kurjenpolven päiväkodissa hakeutuminen oli yhteinen päätös. Etenkin toinen opettajista, kokenut Tuula, oli kiinnostunut mahdollisuudesta saada välineistöä ja koulutusta. Hän oli vuonna 2009 osallistunut Ekapeliä käsittelevään koulutukseen ja yrittänyt saada siitä asti tietokonetta lasten käyttöön. Kone oli saatu keväällä 2013, mutta koska verkkoyhteyden kanssa oli ongelmia, ei konetta ollut vielä käytetty. Tuula piti itseään tieto- ja viestintätekniikan käytön suhteen aloittelijana. Sähköpostin ja tekstinkäsittelyn käyttö kyllä sujuisi, mutta esimerkiksi tablettia hän ei ollut käyttänyt. ${ }^{6}$ Lakkasuon päiväkodin johtaja Kirsi laittoi hakemuksen matkaan kysymättä henkilöstöltä. Hän oli pari vuotta aiemmin yrittänyt saada silloista esiopetusryhmää mukaan tieto- ja viestintätekniikkaan liittyvään projektiin. ${ }^{7}$ Kuitenkin, koska kunnan sähköisiä hallinto- ja asiakaspalvelujärjestelmiä uusittiin samaan aikaan, oli henkilöstö ilmoittanut olevansa jo täystyöllistetty, eikä halunnut osallistua. Menetetty mahdollisuus harmitti Kirsiä edelleen. Koska lähikoulussa käytettiin TVT:aa runsaasti, tulisi esiopetuksen ja alkuopetuksen toimintakulttuurit saada Kirsin mielestä yhtenäisemmäksi. ${ }^{8}$
Tammikuussa heti ensimmäisen vapaata tietokonekirjoittamista käsitelleen koulutus-/vanhempainillan jälkeen ryhmien käyttöön toimitettiin tietokoneet ja digikamerat. Langaton verkko asennettiin huhtikuussa. Kevään 2014 aikana Anjan ryhmässä työstettiin monia eri teknologioita (esim. tietokone, skanneri, kamerat, tekstinkäsittely, kuvankäsittely) ja tekstilajeja (esim. uutinen, arvoitus, sarjakuva, satu) hyödyntänyt ja tammikuisesta koulutuksesta vaikutteita saanut eskarilehtiprojekti. Lehteä oli työstetty osin kaikkien päiväkodin esiopetusryhmien yhteisissä "pajapäivissä", jolloin myös muiden ryhmien lapset olivat päässeet tutustumaan välineisiin. Lisäksi Anja oli aloittanut tutustumaan muutaman lapsen kanssa graafiseen Scratch-koodausohjelmaan. ${ }^{9}$ Huhtikuun yhteyshenkilötapaamisessa Anja kuitenkin kertoi, että lokakuussa aloittanut uusi johtaja oli ilmoittanut, että hänet siirretään työkierron myötä seuraavaksi toimintakaudeksi 3-5-vuotiaiden lasten ryhmään. Anja kertoi, että häntä: harmittaa aivan vietävästi, että ens syksynä en oo sitten ryhmässä, koska mää siitä puhuin, että eikö hanke kuitenkin sido ihmisiä kun on kuitenkin useamman vuoden hanke-- --et ootko [tilalle tuleva opettaja] valmis sitoutuun----ei sultakaan juuri kyselty. ${ }^{10}$ Niittyvillan johtaja vahvisti Anjan kertomuksen, perustellen päätöstä tiimin toimivuudella. ${ }^{11}$ Meerin vaihtaessa työpaikkaa, jäi Hilkka ainoana alkuperäisenä jäsenenä aloittamaan uutta toimintakautta. $^{12}$

Tuulaa huolestuttivat työnjaolliset kysymykset. Hän tunsi olevansa liiaksi yksin vastuussa TVT:n mukaanotosta opetukseen. Tuulan huolta oli myös lisännyt se, että vieraileva kouluttaja oli kutsunut häntä vahingossa "vastuuhenkilöksi". ${ }^{13}$ Tuulan tiimin toinen opettaja ja lastenhoitaja vaihtuivat seuraavaksi toimintavuodeksi. Niittyvillan johtajan tavoin myös Kurjenpolven johtaja nimesi tiimin toimivuuden syyksi muutokseen. ${ }^{14}$ Lakkasuon esiopetusryhmän henkilöstö vaihtui kokonaisuudessaan kaikkien siirtyessä toisiin päiväkoteihin. ${ }^{15}$

Ryhmille annettiin tablettitietokoneet elokuussa 2014. Yhteiset koulutukset järjestettiin pedagogisina kahviloina, jotka pidettiin vuoron perään kussakin päiväkodissa. Saavutettavuuden varmistamiseksi samansisältöisiä kahviloita oli aina kaksi peräkkäin. 
Vähäisimmillään kahviloihin osallistui kaksi henkeä, joista vain toinen oli hankeryhmistä. ${ }^{16}$ Kurjenpolven päiväkoti joutui muuttamaan yllättäen toisiin tiloihin loppuvuodesta 2014. Pakkaamisesta ja muutosta johtuneet ylimääräiset kiireet olivat vieneet Tuulan tiimiltä mahdollisuuden yhteissuunnitteluun. Tuula oli kompensoinut ajanpuutetta harjoittelemalla tabletin käyttöä omalla ajallaan, koska ei halunnut mennä lasten eteen epävarmana osaamisestaan. Hänen lähitulevaisuuden tavoitteensa olikin, että "jonain päivänä tätä [teknologiaa] voi käyttää niinkö näin, et se ei vaaji enää semmosta illan väkerrystä kotona ensin, niinku, että koeversioita". ${ }^{17}$ Tuula oli kuitenkin tyytyväinen siihen, miten he olivat uudessa tiimissä ottaneet TVT-integraation yhteiseksi asiakseen, ja sanoi kokevansa heillä olevan takanaan johtajan tuki.

Hän piti myös tehtäväkirjojen poisjättöä hyvänä ratkaisuna, sillä sen myötä poistui yksi kiirettä aiheuttava tekijä. ${ }^{18}$

Lakkasuon esiopetusryhmässä alkoi syksyllä sairastelukierre. Heille ei ollut järjestynyt yhteissuunnitteluaikoja, mutta johtaja Kirsi oli pitänyt henkilöstölle sisäisen koulutuksen siitä, miten laitteita tulisi käyttää ${ }^{19}$. Kirsi itse totesi, että hänen täytyy "ihan nenästä vetäen tätä hommaa pyörittää" ja, että tarvitaan "valvontaa", jotta "hommat alkaa oikeasti toimimaan" ja oli pettynyt vallitsevaan tilanteeseen. Esimerkiksi laitteiden toimivuudessa oli ollut syksyllä ongelmia, mutta esiopetustiimi ei ollut ilmoittanut niistä Kirsille tai tutkijalle. ${ }^{20}$ Sairauspoissaolot jatkuivat myös vuodenvaihteen jälkeen, eikä kevätkaudella ole ollut yhtään päivää, jolloin kaikki kolme vakituista työntekijää olisivat olleet samana päivänä paikalla. Sijaisia ei aina saatu ja arki keskittyi työssä jaksamisen ympärille. Henkilöstön jäsenet kokivat, etteivät he ole kyenneet toteuttamaan perustehtäväänsä ja harmittelivat miten vähän olivat TVT:aa pystyneet tavoitteellisesti hyödyntämään. Tiiminsä toimivuuteen ja yhteishenkeen he olivat tyytyväisiä, ja nimesivät toisensa suurimmaksi tekijäksi sille, miksi raskaasta vuodesta oli kuitenkin selvitty ${ }^{21}$

Kevään koulutusmuodoiksi valikoituivat osallistavat koulutukset, jotka olisivat osa tavallista esiopetuspäivää. Kokeilussa työntekijät ja tutkija ideoivat yhdessä kahden tai kolmen päivän mittaisen pedagogisen toimintakokonaisuuden ryhmälle ajankohtaisten keskusaiheiden ympärille. Koulutuspäivinä tutkija toimi osana tiimiä ja uusien pedagogisten ja teknisten aspektien harjoittelu tapahtui osana toimintaa. Kurjenpolven ryhmässä toteutettiin eri tekniikoita ja sisältöalueita integroinut videosatuprojekti. ${ }^{22}$ Lakkasuolla perehdyttiin puolestaan QR-koodien käyttöön. Heidän kanssaan koulutuspäivistä pystyttiin sairauspoissaoloista johtuen pitämään vain osa alun perin suunnitelluista. ${ }^{23}$

Koulutuksen myötä Lakkasuon esiopetusryhmässä oli keksitty tallentaa kuluvan viikon ruokalistat ja nimipäivät QR-koodien takaa aukeaviksi äänitiedostoiksi. Nämä kaksi teemaa olivat nousseet toimintavuoden aikana lapsille tärkeiksi arjen ilmiöiksi ja QR-koodien avulla haluttiin tukea myös ei-vielä lukutaitoisten lasten toimijuutta mahdollistamalla heille tilaisuus ottaa päivän ruoasta ja nimipäiväsankarista itsenäisesti selvää. Myöhemmin keväällä QRkoodeja hyödynnettiin vielä lasten itse videoimien askarteluohjeiden kanssa niin, että mallikuvan viereen liitettiin koodi, jonka takaa ohjeet avautuivat. ${ }^{24}$ Toukokuussa selvisi, että Lakkasuon esiopetustiimi vaihtuisi kokonaisuudessaan seuraavaksi toimintavuodeksi. Opettajat vaihtuivat työkierron myötä ja lastenhoitaja siirtyi toiseen päiväkotiin. ${ }^{25}$ Tuulan tiimi puolestaan saisi toiveensa mukaisesti jatkaa samalla kokoonpanolla myös seuraavan toimintakauden. ${ }^{26}$

\section{MITÄ KERTOMUS KERTOO?}

Esiopetuksen TVT-kulttuurin kehittäminen näyttää Kirsin kertomuksen perusteella olevan hankkeiden ja ulkoisten substanssiasiantuntijoiden varassa. Tulkinta saa tukea Tuulan kuvauksesta lasten käyttöön tarkoitetun tietokoneen ja verkkoyhteyden hankkimisen vaivalloisuudesta. Koska kunnallinen varhaiskasvatusjärjestelmä ei tarjoa välineitä ja koulutusta (Hujala ym. 2012), on ymmärrettävää, että tämän tutkimuksen kontekstina olevan hankkeen kaltaisiin tilaisuuksiin halutaan tarttua. Koska hankkeen tavoitteena oli nimenomaisesti kasvatuskäytännön kehittäminen, olivat opettajat ja hoitajat ammattiryhmiä, joita muutokset välittömimmin koskettaisivat. Kirsin ja osin myös Anjan kertomusten perusteella työntekijöitä ei kuitenkaan aina kuunneltu hakuprosessissa tai ryhmävaihdoksissa. 
Huomionarvoista on myös, että ylimääräinen suunnitteluaika ei toteutunut yhdessäkään päiväkodissa, vaikka tätä lähtökohtaisesti edellytettiin. Kurjenpolven äkillinen muutto toisiin tiloihin on ymmärrettävästi vienyt resursseja, mutta toisaalta suunnitteluaikaa ei järjestynyt myöskään ennen muuttouhan aktualisoitumista tai uusiin tiloihin siirtymisen jälkeen. Kirsin kertomuksessa ainoa työyhteisössä sisäisesti järjestetty TVT:n harjoitteluun varattu aika oli hänen itsensä henkilöstölle pitämä työpaikkakoulutus. Tämä kertoo Kirsillä olleen tahtoa esiopetuksen kehittämiseen ja vahva, mutta myös osin hankkeen tavoitteista poikkeva näkemys kehttämisen suunnasta ja metodeista. Harjoittelulle ja yhteiselle keskustelulle oli kuitenkin tarve. Osallistavien koulutuspäivien myötä Lakkasuon esiopetustiimi sai mahdollisuuden miettiä yhdessä, mitä TVT:n pedagoginen käyttö voisi heidän ryhmässään tarkoittaa. Soveltuvan teknologian löydyttyä, he alkoivatkin kehittää omia persoonallisia käytänteitään. Tuula puolestaan päätti käyttää vapaa-aikaansa teknisten ja pedagogisten sisältöjen opetteluun. On kuitenkin muistettava, ettei resursointi ole vain päiväkodinjohtajien päätettävissä. Vaatimus määräaikaisten työsopimuksien ketjuttamiseen ja sijaiskiellot ovat Fonsénin $(2014,158)$ mukaan 2010-luvulle tyypillinen johtavia kuormittava ilmiö.

Työkierron ja työpaikkavaihtojen myötä usein vain yhden toimintavuoden mittaisiksi jääneet työsuhteet tai ryhmäsijoitukset ovat TVT-integraatioon tähtäävän työssä oppimisen näkökulmasta riittämättömän lyhyitä jaksoja (Orlando 2014). Runsas vaihtuvuus haastaa myös osallisuutta ja sitoutumista. Lakkasuon esiopetusryhmän henkilöstön vaihduttua kokonaisuudessaan ei kukaan elokuussa 2014 aloittaneista työntekijöistä ollut lähtökohtaisesti sitoutunut hankkeen tavoitteisiin. Niin ikään laitteistohankinnat ja syyskauden 2014 koulutussisällöt oli suunniteltu ja sovittu ennen heidän mukaantuloaan. Tätä vasten on ymmärrettävää, että liikkeellelähtö vei aikaa, eikä motivaatiota ehkä aluksi ollut. Lisäksi tiimien toistuvan vaihtumisen on havaittu kuormittavan sekä ryhmään jääviä että uusia työntekijöitä. Toisaalta, kuten Tuulan kertomus osoittaa, voi työkierrolla olla toimivien tiimien löytymisen kautta myös

\section{TVT-KULTTUURIN}

\section{KEHITT ÄMINEN NÄYTT $\ddot{A}$}

\section{OLEVAN HANKKEIDEN}

\section{JA ULKOISTEN}

\section{ASIANTUNTIJOIDEN}

VARASSA.

myönteisiä puolia. (Karila \& Kupila 2010, 54-60; Rouvinen 2007, 151-152.) Laajempi osallistuminen omissa päiväkodeissa pidettyihin pedagogisiin kahviloihin olisi voinut vähentää työkierrosta aiheutuneita haasteita. On kuitenkin ymmärrettävää, että ilman olemassaolevia välineitä (tai lupausta tulevista välineistä), ei osallistumista TVT-koulutuksiin koeta mielekkääksi.

Työkierron taustalla olevat tekijät jäivät kertomuksessa hahmottomiksi johtajien perusteltua vaihdoksia laveasti tiimien toimivuudella. Karilan ja Kupilan $(2010,58)$ mukaan kokemustieto on päiväkotityössä arvostettua ja merkityksellistä pääomaa, ja on mahdollista, että juuri Hilkan kokemus esiopetuksesta oli yksi merkittävimmistä tekijöistä siinä, että juuri hän jäi ryhmään eikä ensimmäistä vuotta esiopetuksessa työskennellyt Anja. Tulkintaa tukee, että Tuula kokeneena esiopettajana oli se, joka sai jäädä esiopetusryhmään muiden jäsenten vaihtuessa työkierron myötä syksyksi 2014.

Anjan tapauksessa työkierron aiheuttama kertomuksen katkeaminen näyttäytyy erityisen jyrkkänä. Toisin kuin Lakkasuon henkilöstö, hän oli merkittävässä roolissa hankkeeseen hakeutumisessa. Toinen opettaja nimesikin Anjan ja lastenhoitaja-Meerin TVT-osaamisen tärkeäksi tekijäksi siihen, miksi hänkin epävarmempana koki hakeutumisen mielekkäänä. Anja oli myös hyvin sitoutunut työn kehittämiseen ja oletti, että hankkeeseen osallistuminen tarkoittaisi ryhmän pysyvyyttä. Ryhmässä toteutettiinkin jo keväällä 2014 käytänteitä, joiden kaltaisiin muissa ryhmissä päästiin vasta myöhemmin ja runsaamman tuen myötä. 
Anjan kertomus kuvaa myös sitä, että työssä oppimisen mahdollisuuksia ei aina tunnisteta. Konkreettista esimerkkiä näyttävien kollegojen on havaittu tukevan epävarmojen opettajien TVT-integraatioprosessia (Angeli 2004; Aubrey \& Dahl 2014). Täten Anjan tapauksessa työkierto ei vain vienyt häneltä mahdollisuutta toteuttaa tieto- ja viestintätekniikkaan liittyviä intressejään uudessa ryhmässä, mutta myös muilta mahdollisuuden hyödyntää hänen osaamistaan. Anjan kertomus kuvaa myös esiopetuksen eriytynyttä asemaa sekä päiväkotiyhteisössä että osana varhaiskasvatuksen jatkumoa (ks. Rutanen \& Karila 2013, 20-21; Ylitapio-Mäntylä 2009, 200-204). Ryhmärajat ylittävää yhteistyötä tapahtui vain päiväkodin eri esiopetusryhmien välillä, ja rahoituslähteen asettamien rajausten vuoksi konkreettiset kehittämistoimet oli mahdollista suunnata vain esiopetukseen.

\section{LOPUKSI}

Tutkimukseni tulokset viittaavat siihen, että jos varhaiskasvatuksen pedagogiikkaa halutaan kehittää työssä oppimisen kautta, tulee päiväkotityön organisatoriset ja pedagogiset traditiot asettaa kriittisen tarkastelun alle. Kärjistäen voi todeta, että koko päiväkotiorganisaatiossa vallitsee tiimitasolla tunnistettu uusintavaan sosialisaatioprosessiin pyrkivä kulttuuri: uusi tulokas, ihminen tai asia halutaan sopeuttaa vallitseviin käytäntöihin sen sijaan, että niitä reflektoitaisiin ja uudistettaisiin.

Tässä tutkimuksessa työkierto kulki omaa rataansa kahdelle toimintavuodelle sijoittuvasta hankkeesta pahemmin välittämättä, eikä työkulttuurin muuttamista edellyttänyt ylimääräinen suunnitteluaika toteutunut yhdessäkään ryhmässä. Paradoksaalisesti päiväkodin rutiinia arvostava työkulttuuri haastaa uusien rutiinien kehittymisen. Tuulan ryhmä eliminoi yhden, 1990-luvun puolenvälin esiopetusuudistuksen luoman rutiinin jättämällä pois tehtäväkirjat (ks. Rutanen \& Karila 2013, 20-21), mutta toiset perinteet istuvat kuitenkin tiukemmassa. Tuula kertoi, että hän voi käyttää TVT-välineitä lasten kanssa vain silloin kun hän hallitsee niiden käytön hyvin, tuottaen näin mallitarinaa kaikkitietävästä opettajasta (Syrjälä 2002). Esiopetuksen opetussuunnitelman perusteet kuitenkin korostavat oivaltamisen ja uuden löytämisen iloa sekä epäonnistumisten sie- tämistä. TVT-osaamisen kohdalla ne puhuvat sisältötasolla ohjelmiin tutustumisesta ja metoditasolla kokeilusta. (Opetushallitus 2014, 17-18.) Koska TVT:n pedagogisen käytön kohdalla sekä henkilöstö että lapset ovat usein uuden äärellä, ja ajan puute kaikkia osakertomuksia yhdistävä piirre, onkin aiheellista miettiä, missä määrin tavoitteellinen työssä oppiminen voisi TVT:n kontekstissa tapahtua rinnakkain lasten oppimisen kanssa. Tarvetta yhteiseen suunnitteluun ja reflektioon tämä ei poista, mutta tarjoaa kontekstin autenttiselle tutkivalle ja ongelmalähtöiselle oppimiselle.

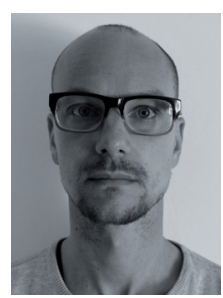

Pekka Mertala

KM, LTO

Projektitutkija

Oulun yliopisto,

Kasvatustieteiden tiedekunta

\section{LÄHTEET}

Angeli, C. (2004). The effects of case-based learning on early childhood pre-service teachers' beliefs about the pedagogical uses of ICT. Journal of Educational Media, 29(2), 139-151.

Aro, M. (2006). Työsuhteiden epävakaistuminen ja työssäoppimisen edellytykset. Teoksessa: Mäkinen, J., Olkinuora, E., Rinne, R. \& Suikkanen, A. (toim.) Elinkautisesta työstä elinikäiseen oppimiseen. Jyväskylä: PS-kustannus, 203-220.

Aubrey, C., \& Dahl, S. (2014). The confidence and competence in information and communication technologies of practitioners, parents and young children in the Early Years Foundation Stage. Early Years, 34(1), 94-108.

Bamberg, M. (2004). Considering Counter Narratives. Teoksessa Bamberg, M., \& Andrews, M. (toim.) Considering counter-narratives: Narrating, resisting, making sense. John Benjamins Publishing, 351-372.

Boje, D. M. (2001). Narrative methods for organizational \& communication research. London: Sage.

Bruner, J. S. (1986). Actual Minds, Possible Worlds. Cambridge, Mass: Harvard University Press. 
Collin, K. (2005). Experience and shared practice: Design engineers' learning at work. Jyväskylä studies in education, psychology and social research 261. Jyväskylä: Jyväskylä University Printing House.

Czarniawska, B. (1998). A narrative approach to organization studies (Vol. 43). London: Sage.

Engeström, Y., Kerosuo, I. \& Kajamaa, A. (2008). Vaikuttavuuden arvioinnista seuraamusten tutkimukseen. Teoksessa: Mäkitalo, J., Turunen, J. \& Vilkkumaa, I. (toim.) Vaikuttavuus muutoksessa. Oulu: Verve, 19-44.

Estola, E. (2003). Hope as work - student teachers constructing their narrative identities. Scandinavian Journal of Educational Research, 47(2), 181-203.

Fonsén, E. (2014). Pedagoginen johtajuus varhaiskasvatuksessa. Acta Universitatis Tamperensis 1914. Tampere: Suomen Yliopistopaino Oy.

Gialamas, V., \& Nikolopoulou, K. (2010). In-service and pre-service early childhood teachers' views and intentions about ICT use in early childhood settings: A comparative study. Computers \& Education, 55(1), 333-341.

Heikkinen, H. L. T. (2002). Narratiivisuus - ei yksi vaan monta tarinaa. Teoksessa: Heikkinen, H.L.T. \& Syrjälä, L. (toim.) Minussa elää monta tarinaa - kirjoituksia opettajuudesta. Helsinki: Kansanvalistusseura, 184-197.

Hujala, E., Backlund-Smulter, T., Koivisto, P., Parkkinen, H., Sarakorpi, H., Suortti, O., Niemelä, T., Kuronen, I., Knubb-Manninen, G., SmedsNylund, A.-S., Hietala, R. \& Korkeakoski, E. (2012). Esiopetuksen laatu. Koulutuksen arviointineuvoston julkaisuja 61. Jyväskylä: Jyväskylän yliopistopaino.

Karila, K., Harju-Luukkainen, H., Juntunen, A., Kainulainen, S., Kaulio-Kuikka, K., Mattila, V. Rantala, K., Ropponen, M., Rouhiainen-Valo, T., Sirén-Aura, M., Goman, J., Mustonen, K. \& Smeds-Nylund, A.-S. (2013). Varhaiskasvatuksen koulutus Suomessa. Arviointi koulutuksen tilasta ja kehittämistarpeista. Korkeakoulujen arviointineuvoston julkaisuja 7:2013. Saatavilla: http://www.kka.fi/files/1960/KKA_0713.pdf [luettu 7.1.2015]

Karila, K. \& Kupila, P. (2010). Varhaiskasvatuksen työidentiteettien muotoutuminen eri ammattilaissukupolvien ja ammattiryhmien kohtaamisessa. Työsuojelurahaston hanke 108267. Loppuraportti. Saatavilla: https://www.tsr.fi/c/ document_library/get_file?folderld=13109\&name $=D$ LFE-4301.pdf [luettu 1.9.2015]

Karila, K. \& Nummenmaa, A.R. (2001). Matkalla moniammatillisuuteen. Kuvauskohteena päiväkoti. Helsinki: WSOY.
Kerckaert, S., Vanderlinde, R., \& van Braak, J. (2015). The role of ICT in early childhood education: Scale development and research on ICT use and influencing factors. European Early Childhood Education Research Journal, 23(2), 183-199.

Lastentarhanopettajan työaikaa koskevat erillismääräykset (2010). Opetusalan ammattijärjestö OAJ.

Opetushallitus (2014). Esiopetuksen opetussuunnitelman perusteet 2014. Saatavilla: http://www. oph.fi/download/163781_esiopetuksen opetussuunnitelman_perusteet_2014.pdf. [luettu 1.9.2015]

Orlando, J. (2014). Veteran teachers and technology: change fatigue and knowledge insecurity influence practice. Teachers and Teaching: theory and practice, 20(4), 427-439.

Palsa, L., Pääjärvi, S., Tossavainen, T., \& Pekkala, L. (2014). Mediakasvatushankkeet 2009-2013 - Selvitys opetus- ja kulttuuriministeriön hallinnonalalla rahoitetuista hankehakemuksista. Kansallisen audiovisuaalisen instituutin julkaisuja 1. Saatavilla: https://kavi.fi/sites/default/files/documents/ kavi_selvitys_mediakasvatushankkeet_2009-2013.pdf [luettu 1.9.2015]

Pekkarinen, A. (2001). Tieto- ja viestintätekniikka lasten ja aikuisten viestinnässä varhaiskasvatuksen alueella. Teoksessa: Kangassalo, M. (toim.) Tietotekniikan mahdollisuuksia varhaiskasvatuksessa. Helsinki: Edita, 78-92.

Polkinghorne, D. (1995). Narrative configuration in qualitative analysis. Teoksessa: hatch. J.A. \& Wisviewski, R. (toim.) Life History and Narrative. Qualitative studies series 1. The Falmer Press, 5-23.

Pääjärvi, S. \& Mertala, P. (2015). Media Education and ICT in Kindergarten Teacher Education: a Study on Finnish University Level Training Programmes Curricula. Posteriesitys EECERA -konferensissa, Barcelona 7-8.9.2015. Saatavilla: https://kavi.fi/sites/ default/files/documents/mertala_paajarvi_2015.pdf [luettu 3.9.2015]

Reunamo, J. (2003). Lapsi tietotekniikkakulttuurin kehittäjänä. (2003). Teoksessa J. Hytönen (toim.) Educational Environment in Early Childhood in Estonia and Finland. University of Helsinki, Department of Teacher education. Research reports 24. 182-196.

Reunamo, J., Söderqvist, H., \& Tanner, K. (2014). Tietotekniikka ja varhaiskasvatus. Teoksessa J. Reunamo (toim.) Varhaiskasvatuksen kehittäminen. Kehitystehtäviä ja ratkaisumalleja. Juva: Bookwell Oy, 162-182.

Rouvinen, R. (2007). "Tässä työssä yhdistyy kaikki": Lastentarhanopettajat toimijoina päiväkodissa. Joensuun yliopiston kasvatustieteellisiä julkaisuja 119. Joensuu: Joensuun yliopistopaino. 
Rutanen, N. \& Karila, K. (2013). Institutionaaliset siirtymät alle kolmivuotiaista viskareiden ja eskareiden kautta kouluun. Teoksessa: K. Karila, L. Lipponen \& K. Pyhältö (toim.) Päiväkodista peruskouluun. Siirtymät varhaiskasvatuksen, esi- ja alkuopetuksen rajapinnoilla. Opetushallitus: Raportit ja selvitykset 2013: 17. 17-24.

Saari, T. Työssä kehittyminen tietotyöntekijä oikeutena ja velvollisuutena. Aikuiskasvatus 33(2), 95-106.

Seppänen-Järvelä, R. (2006). Projekti - kehittämisen kehto vai musta aukko? Yhteiskuntapolitiikka (69)3. 251-259.

Siekkinen, M. \& Ojala, M. (1996). Tietotekniikan integrointi lasten oppimiseen ja opetukseen päiväkotitoiminnassa. Lähtökohtia, tavoitteita ja käytännön sovelluksia Helsingin läntisen sosiaalikeskuksen päiväkodeissa. Helsingin kaupunki, Sosiaalivirasto. Sosiaaliviraston julkaisusarja C/1996.

Syrjälä, S-L. (2002). Kansankynttilä. Teoksessa: Heikkinen, H.L.T. \& Syrjälä, L. (toim.) Minussa elää monta tarinaa - kirjoituksia opettajuudesta. Helsinki: Kansanvalistusseura, 13-19.

Tondeur, J., Cooper, M., \& Newhouse, C. P. (2010). From ICT coordination to ICT integration: A longitudinal case study. Journal of Computer Assisted Learning, 26(4), 296-306.

Venninen, T. (2007). "Olen enemmän alkanut pohtimaan ja sanomaan ääneen mitä ajattelen": ammatillinen kehittyminen ja yhteisöllinen palaute päiväkodin työtiimeissä. Helsingin yliopisto, Käyttäytymistieteiden tiedekunta, Soveltavan kasvatustieteen laitos, Tutkimuksia 282. Helsinki: Yliopistopaino.

Ylitapio-Mäntylä, O. (2009). Hoivaa, opettajuutta ja johtajuutta - Lastentarhanopettajan liikettä päiväkodissa. Teoksessa: H. Ojala, T. Palmu \& J. Saarinen (toim.) Sukupuoli ja toimijuus koulutuksessa. Tampere: Vastapaino. 189-209.

\section{VIITTEET}

1 Esimerkiksi MOLLA, Oivalluksia eskarista!, TiEsi

2 Kaikki nimet ovat pseudonyymejä. Koska aineisto on kerätty julkisesta hankkeesta, ei artikkelissa kerrota yksityiskohtia päiväkodeista informanttien anonymiteetin varmistamiseksi

3 Aineistot, joiden pohjalta kehyskertomus on laadittu, ilmoitetaan loppuviitteissä analyysin läpinäkyvyyden vuoksi

4 Tutkimuspäiväkirja

5 Anjan, Meerin, Hilkan ja johtajan Q yksilöhaastattelut 10/2013

6 Tuulan, opettajan X, lastenhoitajan Y ja johtajan Z yksilöhaastattelut 10/2013; Tuulan kanssa käyty sähköpostivaihto 10-11/2013

7 Kirsin yksilöhaastattelu 10/2013; esiopetushenkilöstön ryhmähaastattelu 10/2013

8 Kirsin yksilöhaastattelu 10/2013

9 Tutkimuspäiväkirja

10 Ryhmäkeskustelu (Tuula, Anja, opettajat W, G ja D) 4/2014

11 Johtajan Q yksilöhaastattelu 12/2014

12 Tutkimuspäiväkirja

13 Ryhmäkeskustelu (Tuula, Anja, opettajat W, G ja D) 4/2014; tutkimuspäiväkirja

14 Johtajan Z yksilöhaastattelu 12/2014

15 Tutkimuspäiväkirja

16 Tutkimuspäiväkirja

17 Tuulan tiimin ryhmähaastattelu 12/2014; Tuulan yksilöhaastattelu 1/2015; johtajan Z yksilöhaastattelu 12/2014;

18 Tuulan tiimin ryhmähaastattelu 12/2014; Tuulan yksilöhaastattelu 1/2015; opettajan C yksilöhaastattelu 1/2015; tutkimuspäiväkirja

19 Opettajan J yksiöhaastattelu 12/2014; Kirsin yksilöhaastattelu 12/2014

20 Kirsin yksilöhaastattelu 12/2014

21 Tutkimuspäiväkirja

22 Tutkimuspäiväkirja

23 Tutkimuspäiväkirja: opettajan F ja lastenhoitajan H parihaastattelu 5/2015.

24 Tutkimuspäiväkirjan merkinnät; opettajan F ja lastenhoitajan H parihaastattelu 5/2015.

25 Opettajan F ja lastenhoitajan $\mathrm{H}$ parihaastattelu 5/2015; opettajan F kanssa käyty sähköpostivaihto $5 / 2015$

26 Tutkimuspäiväkirja 